\title{
Practical approach to COVID-19: an Egyptian pediatric consensus
}

\author{
Abla S. Mostafa ${ }^{1}$, Ashraf Abdalbaky², E. M. Fouda ${ }^{3}$, Hala H. Shaaban", Hala G. Elnady ${ }^{5}$, Magda Hassab-Allah' \\ Mohamed M. Rashad ${ }^{7}$, Mona M. El Attar ${ }^{8}$, Mostafa Alfishawy ${ }^{9}$, Shahenaz M. Hussien ${ }^{10}$, Tarek Hamed ${ }^{11}$, \\ Dina H. Hamed ${ }^{8}$ and Dina T. Sarhan ${ }^{12^{*}}$ (D)
}

\begin{abstract}
Background: Outbreak of a novel corona virus was reported in China on December 2019. Sooner, a global spread was reported and $\mathrm{WHO}$ announced a public health emergency of international concern and then declared it as a pandemic. Egypt announced the first case on February 14, 2020, and since that time, cases are increasing.

Main body: There is increasing need to simplify the practical approach for pediatricians and other health care workers in a step wise manner; how to deal with COVID-19 cases, how to care for the newborn babies as regards to breastfeeding, and how to ensure safety of health care workers assess their risk of infection and management accordingly. A national practical approach guideline was prepared including case definition, diagnosis, and management of pediatric COVID-19 suspected and confirmed cases in an algorithmic pattern.
\end{abstract}

Conclusion: Up to the current knowledge, this is a simple and practical guidance for clinical management of children during the current pandemic.

Keywords: COVID-19, Pandemic, Egyptian, Health care worker, Breastfeeding, Pediatrics

\section{Background}

A novel coronavirus was identified following a cluster of cases of pneumonia in Wuhan, China, in December 2019 [1]. It rapidly spread as an outbreak there. A limited human to human transmission mainly within families was recorded, and the World Health Organization (WHO) announced this on January 22, 2020. On the 23rd of January, it was announced that the outbreak constituted a public health emergency of international concern [2].

WHO designated the disease as coronavirus disease 2019 (COVID-19) and the causative agent severe acute respiratory syndrome coronavirus 2 (SARS-CoV-2) in February 2020 [3]. Few weeks later, virus spread was recorded worldwide and was announced as a pandemic by WHO in March 11, 2020 [4].

\footnotetext{
* Correspondence: dinatawfek7@yahoo.com

${ }^{12}$ Department of Pediatrics, Faculty of Medicine, University Hospital for Children, Zagazig University, Zagazig City, Al-Sharkiya Governorate, Egypt Full list of author information is available at the end of the article
}

Global spread included Egypt, and the first case was recorded in Egypt on February 14, 2020 [5]. The total number of confirmed cases on May 1, 2020, was 5895, with case fatality rate of $6.9 \%$. Children were affected like other age groups, but total incidence was less than $10 \%$. Confirmed cases among health care workers were $11 \%$ of the total confirmed cases [6].

\section{Main text}

Egypt is one of the lower-middle-income countries with limited resources [7] which require a simple and practical clinical guideline to diagnose and treat COVID-19 cases, as well as to protect health care workers from catching infection.

Breastfeeding by COVID-19 mother is another problem that has to be addressed. So, we found a need to advocate this algorithmic approach to simplify these aims.

The science is evolving rapidly and liable to change, and up to the current knowledge, this is a simple and 
practical guidance for clinical management of children during the current pandemic.

\section{Methodology}

This consensus statement is based on expert opinions of pediatric pulmonologists and infectious diseases consultant representing different universities all over Egypt. They are current active members of the Egyptian Pediatric Clinical Practice Guidelines Committee (EPG); several members of the panel have experience with managing pediatric patients during the current pandemic. The panel met via multiple live audio and video conference calls to discuss the most recent international guidelines, data, and recommendations until consensus was achieved [8-12].

The final document is supported by an extensive literature review utilizing the search terms (COVID-19 or SARSCoV2 or Coronavirus 2019 and pediatrics or children).

\section{Discussion}

To minimize the risk of transmission of infection to healthcare workers, these precautions are taken.

\section{In triage (emergency room)}

The child suspected of COVID-19 is transferred to a specialized triage room which is a separate room with good aeration located outside the emergency room (ER)-isolated compartments-prior to any waiting area, better if there is available negative pressure room in the ER. The room contains ready to use soap and hand washing station or alcoholbased hand rub.

The child and his parents wear surgical masks (if tolerated).

All the triage health care workers $(\mathrm{HCW})$ are also instructed to have at least surgical mask, minimize the duration of exposure, and keep safe distance 1-2 m as possible to decrease risk of infection [8].

The examiner doctor and triage personnel who will be taking vitals and assessing patients also must follow the standard and droplet precautions during the examination by wearing their personal protective equipment (PPE) including a respirator (or facemask if respirators are not available), eye protection, and gloves for the primary evaluation of all patients presenting for care until COVID-19 is proved unlikely [13].

\section{Inside the hospital}

As community transmission intensifies within our region, HCW should wear a facemask all times while they are in the healthcare facility. The burden of care lies in the management of suspected cases in the initial 48 -h period prior to the swab results.
Home care is preferable if the child's situation and house condition allows.

When admitted, the patient with known or suspected COVID-19 is placed in a single-person room with the door closed and possible a dedicated bathroom. In the absence of a private room, patients are housed in the same room with at least two meters away in between. Each child can only be accompanied by one caregiver who is provided with a surgical facemask and advised to stay in the room with the child at all times [14].

$\mathrm{HCW}$ who enter the room of a patient with known or suspected COVID-19 should adhere to standard precautions and use a respirator (or facemask if a respirator is not available), gown, gloves, and eye protection with proper hand hygiene [8].

Whenever possible, procedures/tests are performed in the patient's room; nebulization is limited due to the risk of aerosol droplets infection. Instead, metered dose inhalers are preferred [15]. When other aerosol generating procedures are performed, the number of $\mathrm{HCW}$ present during the procedure is limited to only those essential for patient care and procedure support, wearing an N95 respirator, eye protection, overheads, gloves, and a gown. The procedure is followed by cleaning and disinfecting measures for room surfaces promptly [16].

These precautions are to ensure safety of $\mathrm{HCW}$, assess their risk of infection, and manage accordingly (Algorithm 1).

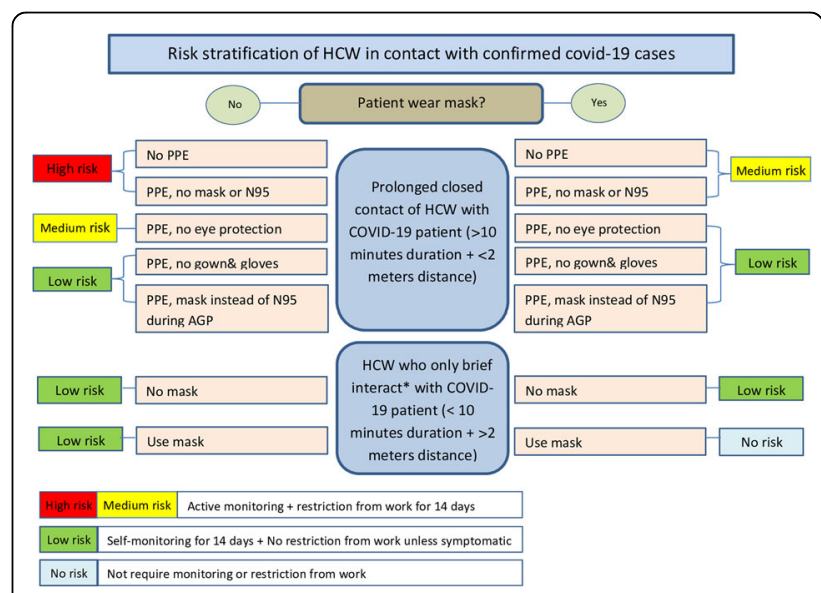

Algorithm 1 Risk stratification of HCW in contact with confirmed COVID-19 cases. Abbreviations: HCW health care worker, AGP aerosol generating procedure, PPE personal protective equipment. *Brief interactions include: brief conversation at a triage desk; briefly entering a patient room but not having direct contact with the patient or the patient's secretions/excretions; entering the patient room immediately after the patient was discharged.

A record of HCW exposed to suspected COVID-19 patient should be maintained and HCW should be encouraged to perform selfmonitoring while awaiting test results. If the results will be delayed more than 72 hours or the patient proved positive for COVID-19, then the monitoring and work restrictions described in this algorithm should be followed 


\section{Diagnosis of COVID-19 cases}

Diagnosis of COVID-19 will depend on a case definition of suspected and confirmed case (Algorithm 2). Implementation of case definition will depend on the clinical presentation of the case and on laboratory test as well as radiological finding. The cases will be stratified according to these collective data to different grades of severity [17].

Mild cases are either asymptomatic or symptomatic with Leucopenia and/or lymphopenia with no radiological evidence of pneumonia (upper respiratory tract illness \pm one of the following symptoms: fever $<38$, cough, GIT symptoms, myalgia and/or arthralgia).

Moderate cases include patients with leucopenia and/or lymphopenia with clinical and radiological evidence of pneumonia, including fever $>38{ }^{\circ} \mathrm{C}$ with or without cough and tachypnea (respiratory rate $>60$ breaths/min for infants $<2$ months, $>50$ breaths $/ \mathrm{min}$ for infants 2-12 months, > 40 breaths/min for children 1-4 years, > 30 breaths/min for children older than 5 years old), and the condition may be associated by moderate to severe dehydration.

Cases are considered as severe and critically ill if any of the following is present:

- $\mathrm{O}_{2}$ saturation $\leq 92 \%$ or $\mathrm{Pa} \mathrm{O} 2 / \mathrm{FiO} 2<200$ despite escalating $\mathrm{O} 2$ therapy to maximal allowed $6 \mathrm{~L} / \mathrm{min}$

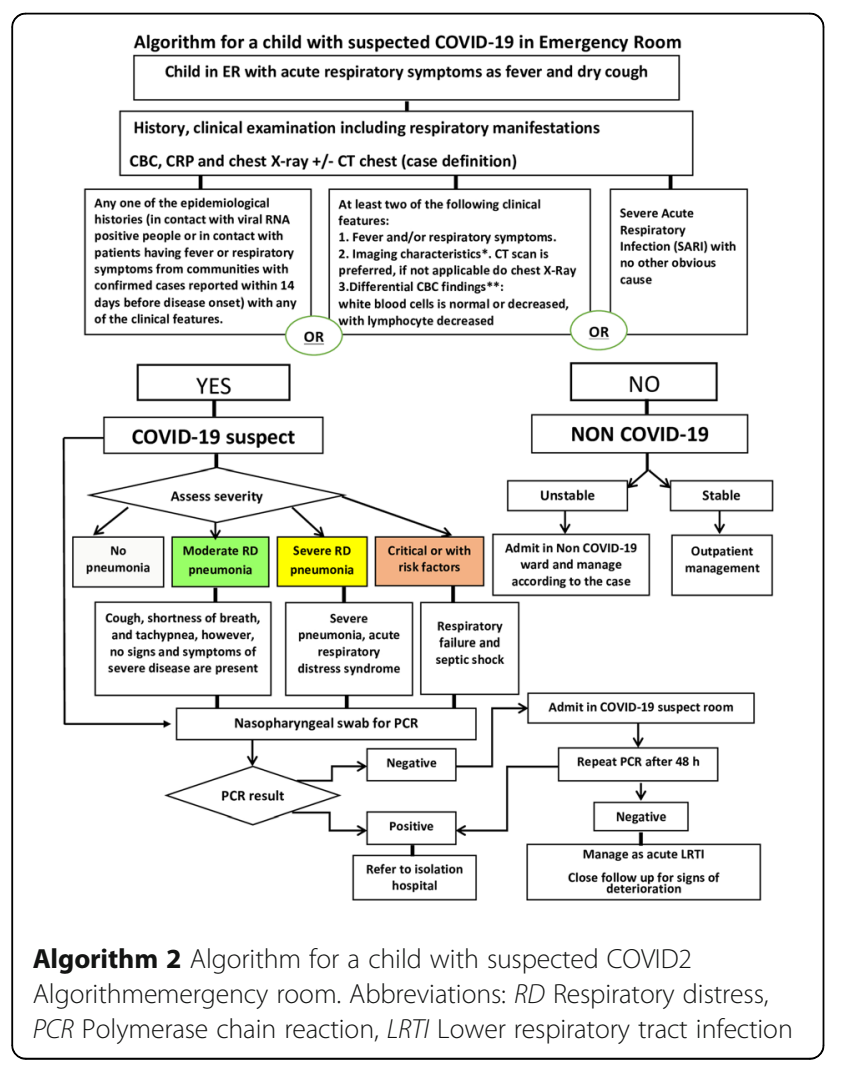

- $\mathrm{O}_{2}$ saturation $\leq 90 \%$ or $\mathrm{Pa} \mathrm{O} 2 / \mathrm{FiO} 2<300$ at room air

- If the patient in septic shock or confused or hemodynamically unstable despite fluid resuscitation

- If respiratory manifestations are combined with other organ failure

- Chest radiography $>50 \%$ lesion or progressive lesion within 24-48 h

\section{Investigations}

For suspected case:

$\mathrm{CBC}$ and radiology

To confirm diagnosis:

Nasopharyngeal swab for PCR

To assess severity:

Serum ferritin, D dimer, LDH, and CRP

\section{Chest radiological abnormalities}

- Chest x-ray abnormalities:

- Bilateral lung infiltrates are found in $75 \%$ of patients, and unilateral lung infiltrates are found in $25 \%$ of patients.

- Abnormalities in C T chest:

- Bilateral multiple lobular and sub segmental areas of ground-glass opacity or consolidation and/or reverse halo sign

- Usually with a peripheral or posterior distribution, mainly in the lower lobes [18].

\section{Laboratory abnormalities}

- CBC: WBCs may be normal or low or high (lymphocytopenia is present in $>80 \%$ in patients). Other findings may include thrombocytopenia and decreased hemoglobin. Neutrophilia: with neutrophil/lymphocyte ratio on $\mathrm{CBC} \geq 3.1$ is characteristic.

- Elevated liver transaminases, CRP, LDH, D-dimer, and serum ferritin.

- Decreased albumin and renal impairment [19].

- IL-6 level if available in sever critical cases.

\section{High-risk children}

1. Any chronic disease such as diabetes, kidney disease, undergoing dialysis, moderate to severe asthma, serious heart conditions, liver disease, and severe obesity $(\mathrm{BMI}>40)$.

2. Immunocompromising conditions including active malignancy, cancer treatment, bone marrow or organ transplantation, poorly controlled HIV or AIDS, and prolonged use of corticosteroids and other immunosuppressive drugs [20]. 
Table 1 Key recommendations for treating pediatric COVID-19 patients according to severity of disease

\begin{tabular}{|c|c|c|c|c|c|c|c|}
\hline $\begin{array}{l}\text { Treatment } \\
\text { Diagnosis }\end{array}$ & Reassurance & $\begin{array}{l}\text { IPC \& Contact } \\
\text { tracing }\end{array}$ & $\begin{array}{l}\text { Symptomatic } \\
\text { treatment }\end{array}$ & Antibiotics & Antivirals & Immunomodulatory & Anticoagulants \\
\hline Asymptomatic & + & + & - & - & - & - & - \\
\hline Mild & + & + & + & - & - & - & - \\
\hline Moderate & + & + & + & + & + & $+/-$ & $\begin{array}{l}\text { Prophylactic or } \\
\text { Therapeutic }\end{array}$ \\
\hline Severe & + & + & + & + & + & $+/-$ & Therapeutic \\
\hline
\end{tabular}

IPC infection prevention and control

\section{Treatment}

Currently, there are no Food and Drug Administration (FDA)-approved drugs for COVID-19. Neither the World Health Organization nor the US Centers for Disease Control and Prevention recommends any specific anti-COVID-19 treatment in children $[9,10]$.

However, an array of drugs approved for other indications, as well as multiple investigational agents, are being studied for treatment and prevention or post-exposure prophylaxis are under way in several hundred clinical trials around the globe [21], but evidence on effective treatments is not yet available; thus, use of specific drugs should be under medical and regulatory supervision to establish safety and efficacy. Current treatment for COVID-19 is mainly supportive care [22].

The decision of the site of management either at home or in hospital depends on the clinical presentation, requirement for supportive care, potential risk factors for severe disease, and the ability of the patient to self-isolate at home [10, 23].

Supportive treatment including sufficient fluid and calories intake, and additional oxygen supplementation should be used in the treatment of children infected with COVID-19. The aim is to prevent ARDS, organ failure, and secondary nosocomial infections. If bacterial infection is suspected, broad-spectrum antibiotics may be used [24].

To make the practical management easy and applicable with the current Egyptian limited resources and available medical facilities, the key recommendations for treating pediatric COVID-19 patients according to severity of disease are summarized in Table 1 and Algorithm 3, pediatric drug doses of used medications are listed in Table 2, with special guide to the indications, contraindications, and pediatric dosing of anticoagulants which are listed in Table $3(\mathrm{a}, \mathrm{b})$; also, the discharge standards and follow-up plan are illustrated in Table 4.

\section{Feeding the newborn of COVID-19 mother}

As breast milk samples from the COVID-19-positive mothers after the first lactation were all negative for the virus, and as breastfeeding is particularly effective against infectious diseases because it strengthens the immune system by several mechanisms including direct transferring of antibodies from the mother, and other anti-infective factors and long-lasting transfer of immunological competence and memory; therefore, all confirmed or suspected COVID-19 mothers with any symptoms who are breastfeeding or practicing skin-to-skin contact should follow standard infant feeding guidelines with appropriate precautions [9, 25] (Algorithm 4).

\section{Conclusion}

Covid-19 is nowadays a community-acquired infection. HCW must wear all recommended PPE to protect themselves from getting infected. Especial care must be considered for newborn baby and to continue as much as possible breast feeding. Diagnosis and management of suspected COVID-19 children must be updated to latest international experience in this field, and implementation of a national guideline is important.

It is important to stress that the treatment recommendations in this paper should not be considered

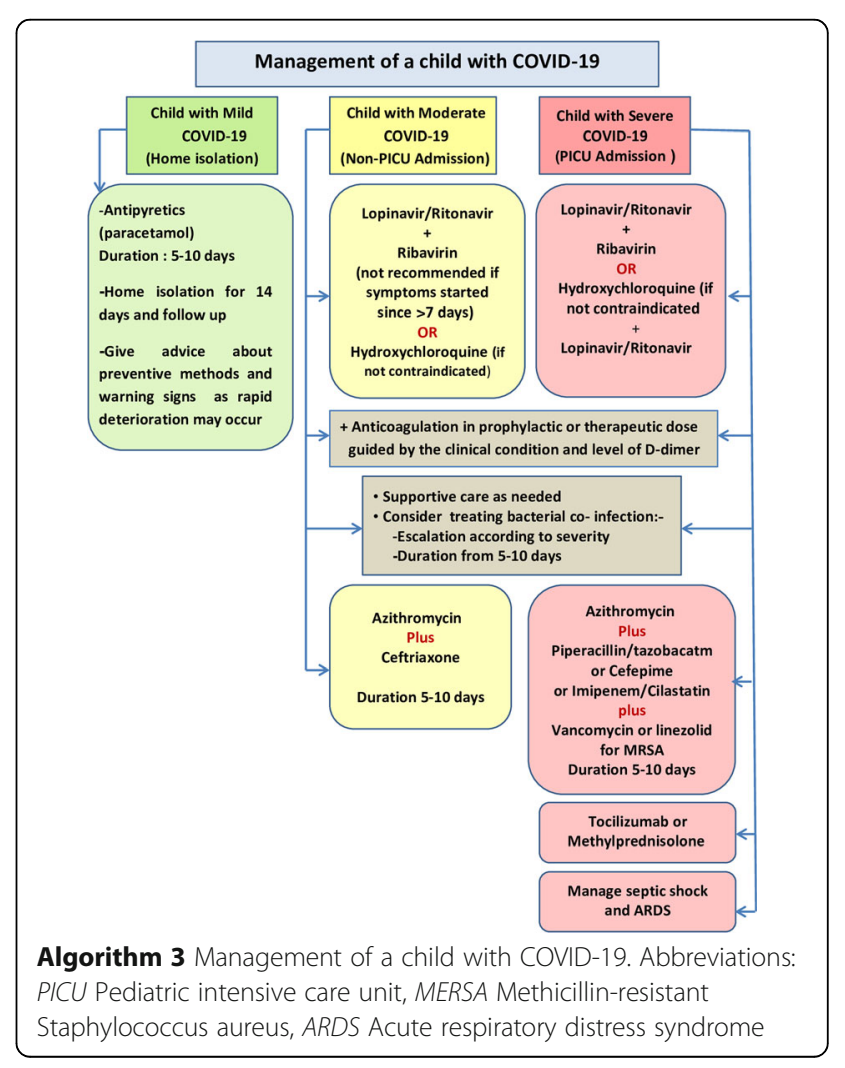


Table 2 Pediatric drug doses of used medications

\begin{tabular}{|c|c|c|}
\hline Drug & Pediatric Dose & Notes \\
\hline Azithromycin & $\begin{array}{l}10 \mathrm{mg} / \mathrm{kg} \text { once on day } 1 \text { (maximum dose: } 500 \mathrm{mg} / \text { dose), } \\
\text { followed by } 5 \mathrm{mg} / \mathrm{kg} \text { (maximum dose: } 250 \mathrm{mg} / \text { dose) once } \\
\text { daily on days } 2 \text { to } 5\end{array}$ & $\begin{array}{l}\text { - Monitor ECG in high risk patients due to the } \\
\text { risk of QTC prolongation. } \\
\text { - For } 5 \text { days }\end{array}$ \\
\hline Ceftriaxone & 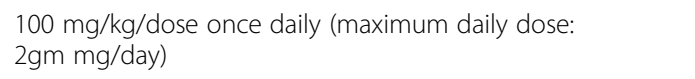 & - For 5-10 days \\
\hline \multirow[t]{3}{*}{ Ribavirine } & \multirow[t]{3}{*}{$\begin{array}{l}\text { children> } 3 \text { years of age: } 15 \mathrm{mg} / \mathrm{kg} / \text { day in } 2 \text { divided } \\
\text { oral doses }\end{array}$} & $\begin{array}{l}\text { - Patients with impaired renal function, adjust } \\
\text { ribavirine dose according to nephrologist advice. }\end{array}$ \\
\hline & & - Monitor $\mathrm{CBC}$, serum creatinine, liver function \\
\hline & & - For 14 days \\
\hline \multirow[t]{4}{*}{ Lopinavir/ Ritonavir } & \multirow{4}{*}{$\begin{array}{l}\text { Dosage based on weight, presented based on mg of } \\
\text { lopinavir; maximum dose: Lopinavir } 400 \mathrm{mg} / \mathrm{ritonavir} \\
100 \mathrm{mg} 7-15 \mathrm{~kg}: 12 \mathrm{mg} / \mathrm{kg} \text { twice daily } 15-40 \mathrm{~kg} \text { : } \\
10 \mathrm{mg} / \mathrm{kg} \text { twice daily > } 40 \mathrm{~kg}: 400 \mathrm{mg} / 100 \mathrm{mg} \text { twice } \\
\text { daily }\end{array}$} & $\begin{array}{l}\text { - Do not use lopinavir/ ritonavir in pre-term or full } \\
\text { term neonates before } 14 \text { days of age. }\end{array}$ \\
\hline & & $\begin{array}{l}\text { - Check for drug-drug interaction (consult clinical } \\
\text { pharmacist). }\end{array}$ \\
\hline & & $\begin{array}{l}\text { - If lopinavir/ritonavir is not available may consider } \\
\text { darunavir/cobicistat as an alternative. }\end{array}$ \\
\hline & & - For 14 days \\
\hline \multirow[t]{9}{*}{ Hydroxychloroquine } & $\begin{array}{l}6.5 \mathrm{mg} / \mathrm{kg} \text { orally every } 12 \text { hours (max: } 600 \mathrm{mg} / \text { dose) for } \\
\text { two doses, followed by } 3 \mathrm{mg} / \mathrm{kg} \text { orally every } 12 \text { hours } \\
\text { (max: } 200 \mathrm{mg} / \text { dose) for a total of 5-10 days }\end{array}$ & - Check contraindications carefully \\
\hline & Contraindication : & - Use with caution in QT interval prolongation \\
\hline & Allergy to 4-aminoquinoline & - Pediatric dose may change based on future studies \\
\hline & Chronic liver and kidney disease or Hematological Disorders & \multirow[t]{6}{*}{ - For 5-10 days } \\
\hline & Patients with arrhythmia and chronic heart disease & \\
\hline & Patients known to have retinal disease or hearing loss & \\
\hline & Skin disorders (including rash, dermatitis, and psoriasis) & \\
\hline & Glucose-6-phosphate dehydrogenase (G6PD) deficiency & \\
\hline & Revise drug drug interaction carefully with pharmacist & \\
\hline Piperacillin/Tazobactam & 300 mg/ kg/day divided every 6-8 hours & $\begin{array}{l}\text { - For 5-10 days but may be extended on a } \\
\text { case-bycase basis }\end{array}$ \\
\hline Vancomycin & 15 mg/kg/dose every 6 hours & $\begin{array}{l}\text { - For 5-10 days but may be extended on } \\
\text { a case-bycase basis }\end{array}$ \\
\hline \multirow[t]{4}{*}{ Tocilizumab } & $<30$ kg: 12 mg/kg & • H score with a value more than 169 \\
\hline & \multirow[t]{3}{*}{$\geq 30$ kg: 8 mg/kg (max: 800 mg/dose) } & - Duration: One dose \\
\hline & & - Response usually seen at 48-72h \\
\hline & & - Don't exceed 800 mg/dose \\
\hline Methylprednisolone & 2 mg/kg/day & - For 3-5 days when Tocilizumab not available \\
\hline
\end{tabular}


Table 3 Pediatric COVID-19 anticoagulation regimens

\section{a. Doses of anticoagulation}

$$
\text { Prophylaxis Therapeutic dose }
$$

Heparin 100-150 units/kg IV once Infusion

- $<1$ year-loading dose of 75 units $/ \mathrm{kg}$ IV, then 28 units $/ \mathrm{kg} / \mathrm{h}$ IV as initial maintenance dose

- 1 year-Loading dose of 75 units $/ \mathrm{kg}$ IV, then 20 units $/ \mathrm{kg} / \mathrm{h} \mathrm{IV}$ as initial maintenance dose

Intermittent IV injection

- Initially give 50-100 units/kg IV infusion, then 100 units/kg IV infusion q4hr as a maintenance dose

Enoxaparin < 2 months: $0.75 \mathrm{mg} / \mathrm{kg} \mathrm{SC} \mathrm{q12h} \mathrm{<} 2$ months: $1.5 \mathrm{mg} / \mathrm{kg} \mathrm{SC} \mathrm{q12h}$

$\geq 2$ months: $0.5 \mathrm{mg} / \mathrm{kg}$ SC q12hr $\geq 2$ months: $1 \mathrm{mg} / \mathrm{kg} \mathrm{SC} \mathrm{q12hr}$

\section{b. Indications and contraindications of anticoagulation}

Indications for prophylactic anticoagulation

Indications for therapeutic anticoagulation

Contraindications
All admitted patients with moderate COVID-19, i.e., any patient with pneumonia All moderate and severe cases who don't meet the therapeutic indications

All ICU patients

O2 sat $<92 \%$ or tachypnea for age

$\mathrm{O} 2$ requirements $\geq 4 \mathrm{~L}$ on nasal cannula

Elevated D-dimer 3x upper level of normal

Elevated CRP

Patients who are at high risk of bleeding

Platelets $<50,000$

INR $>1.5$

Active bleeding

Table 4 Discharge standards and follow-up plan

\begin{tabular}{|c|c|c|}
\hline Discharge standards & Medication after discharge & Follow-up plan \\
\hline $\begin{array}{l}\text { 1- Body temperature: normal for }>3 \text { days. } \\
\text { 2- Respiratory symptoms: significantly improved. } \\
\text { 3- PCR: negative for respiratory tract pathogen } \\
\text { twice }(48 \mathrm{~h} \text { apart). } \\
\text { 4- Lung imaging: showing obvious improvement. } \\
\text { 5- No comorbidities or complications which require } \\
\text { hospitalization. } \\
\text { 6- } \mathrm{SpO}_{2}>94 \% \text { without assisted oxygen inhalation. } \\
\text { 7- Discharge approved by multi-disciplinary medical team. }\end{array}$ & $\begin{array}{l}\text { Symptomatic Treatment: as needed } \\
\text { Antiviral drugs: for patients with multiple } \\
\text { lung lesions in the first } 3 \text { days after their } \\
\text { nucleic acid tests are negative. }\end{array}$ & $\begin{array}{l}\text { Follow-up call: within } 48 \mathrm{~h} \text { after } \\
\text { discharge. } \\
\text { Outpatient follow-up: } 1 \text { week, } \\
2 \text { weeks after discharge. } \\
\text { Examinations: include } \\
\text { - CBC\&CRP } \\
\text { - Lung CT scan according to } \\
\text { the patient's condition. } \\
\text { - PCR test of sputum and stool samples. } \\
\text { - Liver and kidney functions, } \\
\text { Follow-up phone calls: } 3 \text { and } \\
6 \text { months after discharge. }\end{array}$ \\
\hline
\end{tabular}




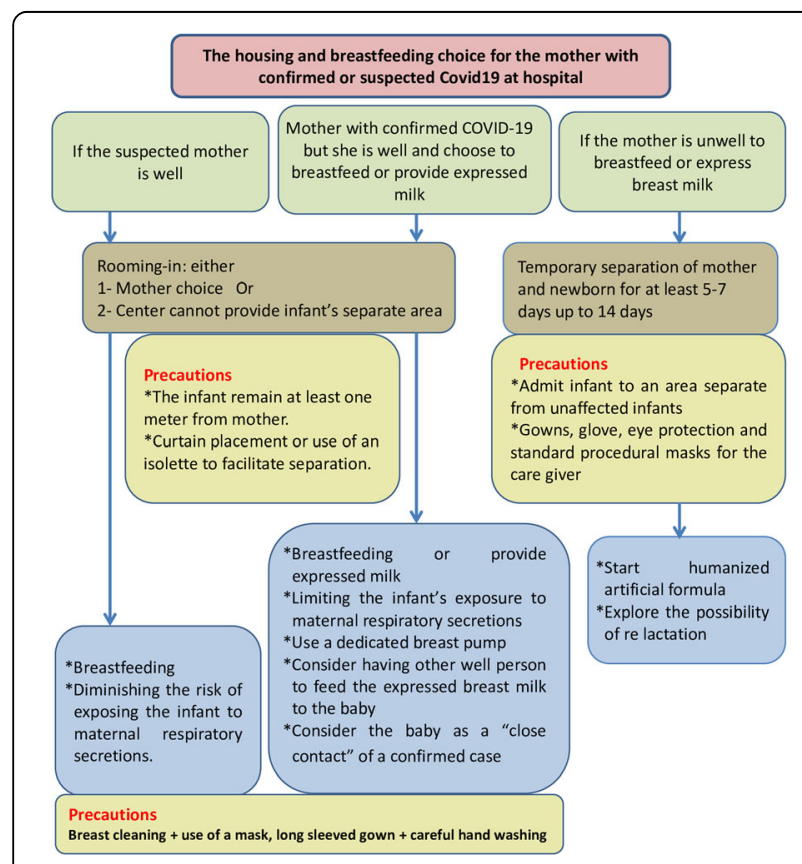

Algorithm 4 The housing and breastfeeding chioce for the mother with confirmed or suspected COVID-19 at hospital

mandates. The choice of what to do or not to do for an individual patient is ultimately decided by the patients together with their health care providers.

\section{Abbreviations}

AIDS: Acquired immunodeficiency syndrome; ARDS: Acute respiratory distress syndrome; CBC: Complete blood count; COVID-19: Coronavirus disease 2019; CRP: C-reactive protein; EPG: Egyptian Pediatric Clinical Practice Guidelines Committee; ER: Emergency room; FDA: Food and drug administration; HCW: Health care workers; HIV: Human immunodeficiency virus; LDH: Lactate dehydrogenase; PCR: Polymerase chain reaction; PPE: Personal protective equipment; WHO: World Health Organization

\section{Acknowledgements}

We have to thank all medical teams all over Egypt, who spend a great effort to care patients and save lives during this pandemic crisis. Their efforts will be a role model inspiring for the future generations.

\section{Authors' contributions}

A.A.: Head of the Egyptian Pediatric Clinical Practice Guidelines Committee $(E P G)$, moderator and coordinator of online meetings, and approved final version. M.M.R., F.E.M., T.H.: Idea of the work, major contributor in writing the manuscript, definition of intellectual content, critically reviewed the manuscript and tables' and algorithms' designs. H.H.S., M.M.E.: Major contributor in writing the manuscript, reviewing the algorithms, tables, and final editing process of the manuscript. M.H., S.M.H.: Major contributor in writing and revising the manuscript and approved final version. A.S.M., H.G. E.: Contribution in writing the manuscript. M.A.: Contributor in writing the manuscript, designing tables, and arrangement of online meetings. D.H.H.: Designing algorithms $(2,3)$, literature search, contributor in writing, and revising the manuscript. D.T.S.: Designing algorithms (1, 3, and 4), literature search, contributor in writing the manuscript, final reviewer of the manuscript, and submitted the manuscript. All authors read and approved the final manuscript.

\section{Funding}

This research did not receive any specific grant from funding agencies in the public, commercial, or not-for-profit sector.

\section{Availability of data and materials}

Authors can confirm that all relevant data are included in the article and/or its supplementary information files.

\section{Ethics approval and consent to participate}

Not applicable

\section{Consent for publication}

Not applicable

\section{Competing interests}

The authors declare that they have no competing interests.

\section{Author details}

${ }^{1}$ Pediatric Pulmonology, Faculty of Medicine, Cairo University, Giza, Egypt.

${ }^{2}$ Pediatrics, Faculty of Medicine, Ain-Shams University, Cairo, Egypt. ${ }^{3}$ Pediatric Pulmonology, Faculty of Medicine, Ain-Shams University, Cairo, Egypt.

${ }^{4}$ Pediatric Pulmonology and Allergy, Faculty of Medicine, Cairo University, Giza, Egypt. ${ }^{5}$ Child Health, Medical Division, National Research Center, Giza, Egypt. ${ }^{6}$ Pediatrics, Faculty of Medicine, Al-Azhar University, Cairo, Egypt. ${ }_{7}$ Pediatrics and Pediatric Pulmonology, Faculty of Medicine, Benha University, Benha, Egypt. ${ }^{8}$ Pediatrics, Faculty of Medicine, Cairo University, Giza, Egypt. ${ }^{9}$ Infectious Disease, Aswan Heart Center, Aswan, Egypt. ${ }^{10}$ Pediatrics, Faculty of Medicine, Al-Azher University, Cairo, Egypt. ${ }^{11}$ Pediatric Department, Faculty of Medicine, Zagazig University, Zagazig, Egypt. ${ }^{12}$ Department of Pediatrics, Faculty of Medicine, University Hospital for Children, Zagazig University, Zagazig City, Al-Sharkiya Governorate, Egypt.

Received: 18 May 2020 Accepted: 9 July 2020

Published online: 28 August 2020

\section{References}

1. Centers for Disease Control and Prevention. 2019 Novel coronavirus, Wuhan, China. Information for Healthcare Professionals. https://www.cdc. gov/coronavirus/2019-nCoV/hcp/index.html (Accessed 1 May 2020)

2. WHO Timeline-Covid19. https://www.who.int/news-room/detail/27-04-2020who-timeline\%2D\%2D-covid-19. (Accessed 1 May 2020)

3. World Health Organization. Director-General's remarks at the media briefing on 2019-nCoV on 11 February 2020. https:/www.who.int/dg/speeches/ detail/who-director-general-s-remarks-at-the-media-briefing-on-2019-ncovon-11-february-2020. (Accessed 1 May 2020).

4. WHO Director-General's opening remarks at the media briefing on covid-19 https://www.who.int/dg/speeches/detail/who-director-general-s-openingremarks-at-the-media-briefing-on-covid-19\%2D\%2D-11-march-2020 (Accessed 6 May 2020)

5. Updates on COVID-19 (coronavirus disease- 2019) local situation. https:// www.moh.gov.eg/covid-19 (Accessed 1 May 2020)

6. WHO. COVID-2019 situation report-26. 2020. https://www.who.int/docs/ default-source/ coronaviruse/situation-reports/20200215sitrep-26-covid-19. pdf?sfvrsn=a4cc6787_2 (Accessed 1 May 2020)

7. World bank, data of Egypt, Arab Rep., lower middle income https://data. worldbank.org/?locations=EG-XN (Accessed 1 May 2020).

8. Interim Infection Prevention and Control Recommendations for Patients with Suspected or Confirmed Coronavirus Disease 2019 (COVID-19) in HealthcareSettings. (17 March 2020) Available at: https://tools.cdc.gov/ medialibrary/index.aspx\#/media/id/405869

9. World Health Organization. WHO interim guidance on clinical management of severe acute respiratory infection when novel coronavirus ( $\mathrm{nCoV}$ ) infection is suspected (2020). Available at: https://apps.who.int/iris/handle/1 0665/330893. (Accessed 5 March 2020).

10. Centers for Disease Control and Prevention. Interim clinical guidance for management of patients with confirmed 2019 novel coronavirus (2019-nCoV) infection (2020). Available at: https://www.cdc.gov/ coronavirus/2019-ncov/hcp/clinical-guidance-management-patients.html. (Accessed 21 Feb 2020) 
11. David J C, Michael S B (2020). Coronavirus disease 2019 (COVID-19) treatment \& management. Available at: https://emedicine.medscape.com/ article/2500114-treatment. (Accessed: 7 May 2020).

12. Mount Sinai Health System Treatment Guidelines for SARS - CoV - 2 Infection (COVID - 19) (May 4, 2020) https://www.mountsinai.org/files/ MSHealth/Assets/HS/About/Coronavirus/MSHS-Treatment-Guidelines-COVID. pdf. (Accessed: 9 May 2020).

13. Coronavirus disease 2019 (COVID-19): evaluation and testing. Available at: https://www.cdc.gov/coronavirus/2019-ncov/hcp/guidance-risk-assesmenthcp.html. (Accessed May5th 2020)

14. Thampi S, Yap A, Fan L, Ong J. (2020). Special considerations for the management of COVID-19 pediatric patients in the operating room and pediatric intensive care unit in a tertiary hospital in Singapore. Pediatr Anesth 00:1-5. https://doi.org/https://doi.org/10.1111/pan.13863

15. COVID-19: GINA Answers to Frequently Asked Questions on asthma management. March 25, 2020 https://ginasthma.org/

16. CDC website, Coronavirus disease 2019 (COVID-19): infection control (2020). Available at: https://www.cdc.gov/coronavirus/2019-ncov/infection-control/ index.html. (Accessed 4 June 2020)

17. Management protocol for COVID-19 patients. Egyptian Ministry of Health. Version 1.4 /30th May 2020. Available at: http://www.mohp.gov.eg/ JobsDetails.aspx?job id=3061. (Accessed 8 June 2020)

18. Yoon SH, Lee KH, Kim JY, Lee YK, Ko H, Kim KH, et al.(2020) Chest radiographic and $\mathrm{CT}$ findings of the 2019 novel coronavirus disease (COVID19): analysis of nine patients treated in Korea. Korean J Radiol ;21 (4): 494-500. doi: https://doi.org/10.3348/kir.2020.0132. Epub 2019 Feb 26.

19. Wang D, Ju XL, Xie F, Lu Y, Li FY, Huang HH et al (2020) Clinical analysis of 31 cases of 2019 novel coronavirus infection in children from six provinces (autonomous region) of northern China. Zhonghua Er Ke Za Zhi 58:E011

20. Tang B, Braganza NL, Li Q, Tang S, Xiao Y, Wu J (2020) An updated estimation of the risk of transmission of the novel coronavirus (2019-nCov). Infect Dis Model 5:248-255

21. COVID-19 Treatment Guidelines Panel. Coronavirus Diseases 2019 (COVID19) Treatment Guidelines. National Institutes of Health. Available at https://www.covid19treatmentguidelines.nih.gov/. Accessed [10/5/2020].

22. Jonathan D K, Berthold K, El-Shabrawi M H, Adamos H, Naveen T, Zulfiqar B (2020). Promoting and supporting children's health and healthcare during COVID-19 - international Paediatric association position statement. Arch Dis Child; 0:1-5. doi:https://doi.org/10.1136/archdischild-2020-319370

23. Chen ZM, Fu JF, Shu Q, Chen YH, Hua CZ, Li FB, et al (2020). Diagnosis and treatment recommendations for pediatric respiratory infection caused by the 2019 novel coronavirus. World J Pediatr.5:1-7. https://doi.org/https://doi. org/10.1007/s12519-020-00345-5

24. Petra Z, Nigel C (2020) Coronavirus infections in children including COVID19. An overview of the epidemiology, clinical features, diagnosis, treatment and prevention options in children. Pediatr Infect Dis J 39(5):355-368

25. WHO. Breastfeeding advice during the COVID-19 outbreak. (2020) Available at: http://www.emro.who.int/nutrition/nutrition-infocus/breastfeedingadvice-during-covid-19-outbreak.html (Accessed 8 May 2020)

\section{Publisher's Note}

Springer Nature remains neutral with regard to jurisdictional claims in published maps and institutional affiliations.

\section{Submit your manuscript to a SpringerOpen ${ }^{\circ}$ journal and benefit from:}

- Convenient online submission

- Rigorous peer review

- Open access: articles freely available online

- High visibility within the field

- Retaining the copyright to your article

Submit your next manuscript at $\boldsymbol{\nabla}$ springeropen.com 